\title{
The High Court, the Constitution and Australian Politics
}

The High Court, the Constitution and Australian Politics is an in-depth exploration of the relationship between decisions of the High Court and broader political currents in Australia.

It begins with an investigation of the patterns and effects of constitutional invalidation and dissent on the High Court over time, and their correlation with political trends and attitudes. It also examines the role of constitutional amendment in expressing popular constitutional understandings in the Australian system.

Subsequent chapters focus on the eras marked by the tenure of the Court's 12 Chief Justices, examining the decisions of the Court in the context of the prevailing political conditions.

Together, the chapters canvass a rich variety of accounts of the relationship between constitutional law and politics in Australia, and of how this relationship is affected by factors such as the process of appointment for High Court judges and the Court's willingness to consider political and community values.

With contributors from among Australia's leading constitutional lawyers and political scientists, this book is an important contribution to the fields of both law and politics, and to comparative constitutional law more generally. 
Downloaded from Cambridge Books Online by IP 150.203.87.59 on Thu May 21 01:05:37 BST 2015.

http://ebooks.cambridge.org/ebook.jst?bid=CBO9/8110/445253 


\section{The High Court, the Constitution and Australian Politics}

Edited by

Rosalind Dixon

George Williams 


\section{CAMBRIDGE \\ UNIVERSITY PRESS}

477 Williamstown Road, Port Melbourne, VIC 3207, Australia

Cambridge University Press is part of the University of Cambridge.

It furthers the University's mission by disseminating knowledge in the pursuit of education, learning and research at the highest international levels of excellence.

www.cambridge.org

Information on this title: www.cambridge.org/9781107043664

(C) Cambridge University Press 2015

This publication is copyright. Subject to statutory exception and to the provisions of relevant collective licensing agreements, no reproduction of any part may take place without the written permission of Cambridge University Press.

First published 2015

Cover designed by Anne-Marie Reeves

Typeset by Aptara Corp.

A catalogue record for this publication is available from the British Library

A Cataloguing-in-Publication entry is available from the catalogue

of the National Library of Australia at www.nla.gov.au

ISBN 978-1-107-04366-4 Hardback

\section{Reproduction and communication for educational purposes}

The Australian Copyright Act 1968 (the Act) allows a maximum of one chapter or $10 \%$ of the pages of this work, whichever is the greater, to be reproduced and/or communicated by any educational institution for its educational purposes provided that the educational institution (or the body that administers it) has given a remuneration notice to Copyright Agency Limited (CAL) under the Act.

For details of the CAL licence for educational institutions contact:

Copyright Agency Limited

Level 15, 233 Castlereagh Street

Sydney NSW 2000

Telephone: (02) 93947600

Facsimile: (02) 93947601

E-mail: info@copyright.com.au

Reproduction and communication for other purposes

Except as permitted under the Act (for example a fair dealing for the purposes of study, research, criticism or review) no part of this publication may be reproduced, stored in a retrieval system, communicated or transmitted in any form or by any means without prior written permission. All inquiries should be made to the publisher at the address above.

Cambridge University Press has no responsibility for the persistence or accuracy of URLs for external or third-party internet websites referred to in this publication and does not guarantee that any content on such websites is, or will remain, accurate or appropriate.

Please be aware that this publication may contain several variations of Aboriginal and Torres Strait Islander terms and spellings; no disrespect is intended. Please note that the terms 'Indigenous Australians' and 'Aboriginal and Torres Strait Islander peoples' may be used interchangeably in this publication.

Permission: CLR extracts reproduced with permission of Thomson Reuters (Professional) Australia Limited, www.thomsonreuters.com.au 


\section{Cambridge Books Online}

\section{http://ebooks.cambridge.org/}

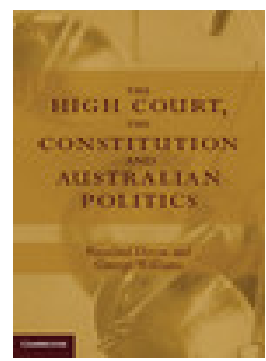

The High Court, the Constitution and Australian Politics

Edited by Rosalind Dixon, George Williams

Book DOI: http://dx.doi.org/10.1017/CBO9781107445253

Online ISBN: 9781107445253

Hardback ISBN: 9781107043664

\section{Chapter}

Foreword by Sir Anthony Mason pp. v-viii

Chapter DOI: http://dx.doi.org/10.1017/CBO9781107445253.017

Cambridge University Press 


\section{Foreword}

The chapters in this chronological survey of constitutional decision-making by the High Court of Australia are arranged by reference to the periods of service of successive Chief Justices of the Court. This arrangement is somewhat problematic because the periods of service of Chief Justices vary considerably and a change in the Chief Justiceship does not necessarily coincide with a change in the Court's pattern of decision-making. Nonetheless, the three thematic chapters on invalidation rates, dissent, and amendment provide an important contextual background for the discussion that follows.

My approach to some of the themes discussed in the chapters is to ignore the temporal divisions by which they are structured and to identify the interpretive approaches and the judicial methodology adopted by the Court over the course of its history. Once this exercise is undertaken, it becomes apparent that the Court's interpretive approaches and its dominant methodology (legalism) for most of its history have been: (i) adapted to meet the requirements of the Australian community as it existed from time to time; (ii) calculated to minimise the risk of decisions which could be considered counter-majoritarian; and (iii) designed to minimise discussion of contentious policy issues.

\section{The early years of Federation}

The first two considerations I have just mentioned were particularly important in the early years of the Court's existence. The Court had to win the confidence of the Australian people and to establish a reputation comparable with that of the Privy Council because the Constitution established the Court as the final arbiter on constitutional inter se questions relating to the powers of the Commonwealth and the states. ${ }^{1}$ On such questions no appeal lay to the Privy Council unless the High Court gave a certificate under s $74 .^{2}$ Only one such certificate has ever been granted $^{3}$ and the power to grant a certificate has now been exhausted. Legislation abolished appeals to the Privy Council from the High Court in 1968 and 1975 and, in 1986, the Australia Act abolished appeals from all Australian courts. ${ }^{4}$

1 Constitution ss 73-74.

2 Constitution s 74.

3 Attorney-General (Cth) v Colonial Sugar Refining Co. Ltd (1914) AC 237, 5.

4 Australia Act 1986 (Cth), s 11. 
The first High Court Justices, who were lawyer-politicians and federalists, adopted two interpretive approaches which protected the position of the states. Taking the view that both the Commonwealth and the states were sovereign, the early High Court adopted the 'implied immunity of instrumentalities' doctrine so that both the states and the Commonwealth were generally immune from each other's laws. The doctrine protected the states and their agencies from the operation of Commonwealth laws.

Invoking the federal nature of the Constitution and picking up the express preservation of state powers by s 107 of the Constitution, the Court developed the 'reserved State powers' doctrine by virtue of which Commonwealth powers were so interpreted that they did not interfere with the residual powers of the states. This doctrine was taken to the point that the Commonwealth's legislative power with respect to interstate trade and commerce could not be exercised so as to intrude upon intrastate trade which was held to be the exclusive province of the states. ${ }^{5}$

By these means the Court substantially reserved to the states certain areas of power which the former colonial legislatures had exercised before Federation. This approach was not unsuited to Australian conditions which were then largely based on state economies and to the state of public opinion which still exhibited colonial parochialisms. But the Court's approach reflected divided opinions. Isaacs and Higgins JJ, who joined the three foundation Justices in 1906, strongly disputed the correctness of the Court's early decisions, as did the Labor Party whose legislative initiatives were struck down. Ultimately the views of the dissenting Justices prevailed in the Engineers Case $^{6}$ decided in 1920.

This decision, the most influential in terms of setting in place the future interpretive approach to the Australian Constitution, rejected the traditional implied doctrines. The notion that the states were sovereign entities was repudiated and with it the doctrine of 'implied immunity of instrumentalities'. The reserved powers doctrine was likewise discarded in favour of a broad and literal interpretation of Commonwealth powers without any derogation to be derived from s 107 . That section merely acknowledged the continued existence in the states of powers not exclusively vested in the Commonwealth by the Constitution on the basis that s 109 resolved any question of inconsistency in the exercise of concurrent powers by the Commonwealth and the states. The section rendered the exercise of state power inoperative to the extent of the inconsistency. Engineers emphasised the importance of responsible government as a fundamental element in the Australian Constitution, thereby differentiating the Australian Constitution from the United States Constitution. In other respects, Engineers continued to apply the English principles of interpretation which had been applied by the early Court.

5 R v Barger (1908) 6 CLR 41; Attorney-General (NSW) v Brewery Employees Union of NSW (the Union Label Case) (1908) 6 CLR 469.

6 Amalgamated Society of Engineers v Adelaide Steamship Co Ltd (1920) 28 CLR 129 ('Engineers Case'). 
The Engineers interpretive approach has been constantly followed. But it is a mistake to view Engineers as simply turning on a different legal perspective. As Sir Victor Windeyer said later in the Payroll Tax Case: ${ }^{7}$

... in 1920 the Constitution was read in a new light, a light that reflected from events that had, over twenty years, led to a growing realisation that Australians were now one people and Australia one country and that national laws might need national needs... [the] Engineers Case, looked at as an event in legal and constitutional history, was a consequence of developments that had occurred outside the law courts, as well as a cause of further developments there.

It was predicted, when the Constitution was adopted, that its provisions would lead to Commonwealth financial domination of the states. And so it proved. The Court's decisions, particularly on uniform taxation and the grants power, have reinforced that domination and have enabled the Commonwealth, by means of the grants power, to dominate, if not dictate, policy in areas such as hospitals, health, and education, being subjects of legislative power not committed to the Commonwealth by the Constitution, except perhaps in minor respects.

The effect of the Engineers interpretive approach has been to endorse a broad application of Commonwealth legislative power despite opposition by the states. The probability is that this approach has resulted in decisions which are majoritarian rather than counter-majoritarian. It is difficult to say that decisions which favour the national government as against a state or states are counter-majoritarian when they uphold the validity of statutes enacted by parliament. And there is no evidence to suggest that there is popular opposition to the steady growth of Commonwealth power; the frequency of claims that particular activities - for example, hospitals, local government - should become a Commonwealth responsibility, based on a belief that increased funding would result, point in the opposite direction. There is academic criticism of what is seen as lack of federal balance but the criticism, in the view of the author, is not anchored in public support.

On the other hand, there have been high-profile cases in which the Court has struck down Commonwealth legislation giving effect to important government policies. The Bank Nationalisation Case $^{8}$ (involving bank nationalisation), the Communist Party Case ${ }^{9}$ (involving the banning of the Communist Party), Australian Capital Television Pty Ltd $v$ Commonwealth, ${ }^{10}$ and the Cross-Vesting Case $^{11}$ are notable examples. The Cross-Vesting Case involved beneficial legislation enacted by the Commonwealth and the states which provided for the cross-vesting of jurisdiction in both federal and state courts. This legislation was struck down on the narrow, non-purposive view that ch III is an exclusive and

7 Victoria $v$ Commonwealth (1971) 122 CLR 353, 395.

8 Bank of NSWv Commonwealth (1948) 76 CLR 1 ('Bank Nationalisation Case').

9 Australian Communist Party $v$ Commonwealth (1951) 83 CLR 1 ('Communist Party Case').

10 (1992) 177 CLR 106. In this case regulations attempting to regulate political broadcasting were invalidated because they infringed the implied freedom of communication on political and government affairs.

11 Re Wakim; Ex parte McNally (1999) 198 CLR 511 ('Cross-Vesting Case'). 
exhaustive statement of the powers and functions of the federal judicature. The counter-majoritarian character of the decision is emphasised by the absence of popular opposition to the legislation.

Engineers also reinforced the legalist methodology which has been employed by the Court for most of its life. The insistence on the importance of textualism and reluctance to engage in evaluation of policy issues meant that, for the most part, the Court has protected itself from controversy over its decisions. Indeed, Sir Owen Dixon advocated the methodology of 'strict and complete legalism' in the resolution of federal questions. ${ }^{12}$

This methodology lent itself to the interpretation of a constitution framed against a background of Dicey's doctrine of parliamentary sovereignty and concerned to allocate powers of government rather than to confer individual rights. It is therefore not surprising that the Court was inclined to view provisions such as s 80 and, initially, s 117 as procedural provisions and s 51 (xxxi) and s 116 as restrictions on the exercise of legislative power. ${ }^{13}$

In the more recent times of Gleeson CJ and French CJ, the Court has been concerned to reinforce and explain its legitimacy by various means, in particular by emphasising the separation of the judicial power from the other powers of government and by insisting on its limitations. The Court has made the point frequently that interpretation is a text-based activity and an aspect of the rule of law and that interpretation cannot extend to a reading that the language of a provision cannot reasonably bear. To travel so far would be to engage in amendment or legislation. In $R v$ Momcilovic, ${ }^{14}$ the Court concluded that the interpretive provision in s 32(1) of the Charter of Human Rights and Responsibilities 2006 Act (Vic) did not authorise an interpretive approach which went beyond the common law principle of legality. In the area of administrative law, the Court has - subject to one recent exception ${ }^{15}$ - been disinclined to apply the ground of Wednesbury unreasonableness ${ }^{16}$ as a basis for reviewing an administrative decision for fear that this may lead to merits review entailing the substitution of the Court's view for that of the executive decision-maker.

The modern focus on legitimacy is consistent with the three elements in the Court's interpretive approach and methodology which I identified earlier in this Foreword.

Sir Anthony Mason

12 Swearing in of Sir Owen Dixon as Chief Justice of the High Court of Australia (1952) 85 CLR xi.

13 As to s 80, see Rv Federal Court of Bankruptcy; Ex parte Lowenstein (1938) 59 CLR 556; Kingswell $v$ The Queen (1985) 159 CLR 264; Cheng $v$ The Queen (2000) 203 CLR 248. As to s 117, see Davies \& Jones $v$ Western Australia (1904) 2 CLR 29; Henry v Boehm (1973) 128 CLR 482; Street v Queensland Bar Association (1989) 168 CLR 461. As to s 51 (xxxi), see Attorney-General (Cth) v Schmidt (1961) 105 CLR 361 at 371 . As to s 116, see Adelaide Company of Jehovah's Witnesses Incorporated v Commonwealth (1943) 67 CLR 116.

14 [2011] HCA 34; [2011] 280 ALR 221.

15 Minister for Immigration and Citizenship v Li [2013] HCA 18.

16 Associated Provincial Picture Houses Ltd v Wednesbury Corporation [1948] 1 KB 223 at 228. 


\section{Contents}

Foreword by Sir Anthony Mason page v

About the editors and authors $\mathrm{xi}$

Acknowledgements xiii

Table of cases $\mathrm{xv}$

Table of statutes $\mathbf{x x v}$

Table of international instruments $\mathbf{x x x i}$

1 Introduction 1

Rosalind Dixon and George Williams

2 Judicial review, invalidation and electoral politics: A quantitative survey 18

Russell Smyth and Vinod Mishra

3 Judicial review and the politics of constitutional amendment 38 Michael Coper

4 Judicial dissent and the politics of the High Court 58 Andrew Lynch

5 The Griffith Court 77

John M. Williams

6 The Knox Court 98

Anne Twomey

7 The Isaacs Court 116

Tony Blackshield

8 The Gavan Duffy Court 141

Gabrielle Appleby

9 The Latham Court 159

Fiona Wheeler 
10 The Dixon Court 179

Helen Irving

11 The Barwick Court 201

Brian Galligan

12 The Gibbs Court 220

Nicholas Aroney and Haig Patapan

13 The Mason Court 244

Paul Kildea and George Williams

14 The Brennan Court 261

Patrick Emerton and Jeffrey Goldsworthy

15 The Gleeson Court 284

Rosalind Dixon and Sean Lau

16 The French Court 311

Anika Gauja and Katharine Gelber

Index 327 


\section{About the editors and authors}

\section{Editors}

Rosalind Dixon is a Professor of Law at the University of New South Wales, Faculty of Law, specialising in comparative constitutional law and constitutional design, theories of constitutional dialogue and amendment, socio-economic rights and constitutional law and gender. She is co-editor of a leading handbook on comparative constitutional law: Comparative Constitutional Law (Edward Elgar, 2011), a related volume on Comparative Constitutional Law in Asia (Edward Elgar, 2014), the Constitutional \& Administrative Law series (Edward Elgar), and is associate-editor of the Hart series on Constitutional Systems of the World. Rosalind is also director of the Project on Comparative Constitutional Law, and former Interim Director of the Gilbert + Tobin Centre of Public Law at the Faculty of Law, University of New South Wales.

George Williams is the Anthony Mason Professor, a Scientia Professor and the Foundation Director of the Gilbert + Tobin Centre of Public Law at the Faculty of Law, University of New South Wales. He has written and edited books such as Australian Constitutional Law and Theory and The Oxford Companion to the High Court of Australia and has appeared as a barrister in the High Court in a number of cases over the past two decades. He has served on a number of public inquiries, and as chair of the Victorian Human Rights Consultation Committee helped bring about Australia's first state Bill of rights: the Victorian Charter of Human Rights and Responsibilities. He is a columnist for the Sydney Morning Herald.

\section{Authors}

Gabrielle Appleby is an Associate Professor at the University of New South Wales, Faculty of Law.

Nicholas Aroney is Professor of Constitutional Law and an Australian Research Council Future Fellow at the Centre for Public, International and Comparative Law, in the TC Beirne School of Law at the University of Queensland.

Tony Blackshield is Emeritus Professor at the Macquarie Law School, Macquarie University. 
Michael Coper is a Professor of Law, ANU College of Law, Australian National University, Canberra.

Patrick Emerton is a Senior Lecturer in the Faculty of Law, Monash University. Brian Galligan is a Professor of Political Science at the University of Melbourne.

Anika Gauja is a Senior Lecturer and an Australian Research Council Discovery Early Career Research Fellow in Government and International Relations, University of Sydney.

Katharine Gelber is a Professor of Politics and Public Policy and an Australian Research Council Future Fellow in Political Science and International Studies at the University of Queensland.

Jeffrey Goldsworthy is a Professor of Law at Monash University.

Helen Irving is Professor of Law at the Sydney Law School, The University of Sydney.

Paul Kildea is a Lecturer at the University of New South Wales, Faculty of Law.

Sean Lau is part of the teaching staff at the University of New South Wales, Faculty of Law.

Andrew Lynch is a Professor of Law at the University of New South Wales, Faculty of Law.

Vinod Mishra is a Senior Lecturer in the Department of Economics, Monash University.

Haig Patapan is Director of the Centre for Governance and Public Policy and Professor in the School of Government and International Relations, Griffith University.

Russell Smyth is a Professor in the Department of Economics, Monash University.

Anne Twomey is a Professor of Law in the Sydney Law School, University of Sydney.

Fiona Wheeler is a Professor in the ANU College of Law, Australian National University.

John M. Williams is the Dean of Law at the Adelaide Law School, University of Adelaide. 


\title{
Cambridge Books Online
}

\author{
http://ebooks.cambridge.org/
}

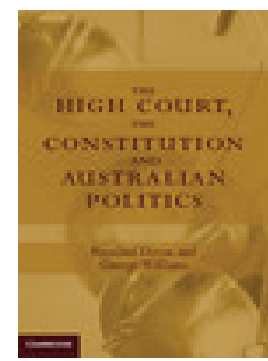

The High Court, the Constitution and Australian Politics

Edited by Rosalind Dixon, George Williams

Book DOI: http://dx.doi.org/10.1017/CBO9781107445253

Online ISBN: 9781107445253

Hardback ISBN: 9781107043664

\section{Chapter}

1 - Introduction pp. 1-17

Chapter DOI: $\underline{\text { http://dx.doi.org/10.1017/CBO9781107445253.001 }}$

Cambridge University Press 


\section{Introduction}

\section{Rosalind Dixon George Williams}

In 1956, Geoffrey Sawer published the first of his two volumes on Australian Federal Politics and Law, 1901-49 - a work that has since become a classic reference in Australian constitutional scholarship. Sawer's central thesis was elegant in its simplicity: there is often a significant disconnect between the political priorities of federal governments in Australia and the opportunities for government action created by constitutional decisions of the High Court. In making this claim, Sawer made an immense contribution to our broader understanding of the political context for High Court decision-making. His work provided a meticulous and comprehensive account of the legislative context for the Court's decisions in the first few decades of its operation.

Since then, a number of works by Australian political scientists have enriched our understanding of the interrelationship between the High Court and Australian federal politics. In a defining book published in 1987, Politics of the High Court: A Study of the Judicial Branch of Government in Australia, Brian Galligan drew the attention of both lawyers and political scientists in Australia to the need to study the High Court as a political institution - an institution that both shapes, and is shaped by, politics. Part of the story Galligan told was a classic legal realist story: behind the rhetoric of Dixon-style 'legalism' on the part of the High Court of Australia, Galligan suggested, were a vast set of complex policy choices. Choices of this kind have had major political significance, and surfacingand acknowledging - these choices is thus critical to assessing the Court's legitimacy. Another part of the story concerned the role of the Australian Labor Party in the Australian constitutional settlement: constitutional stability in Australia, 
Galligan suggested, has in large part been achieved by 'termina[ting] the main disruptive and reforming attempts of federal Labor governments'. ${ }^{2}$

Galligan's path-breaking study ended in 1984. In the 20 years since, Australia has witnessed two extended periods of Labor government: first under Hawke and Keating, and then Rudd and Gillard. It has also seen one of the most controversial - and at the same time openly policy-oriented - eras in High Court history: the Mason Court era. And Australia has seen waves of reaction, and counter-reaction, to that era in the Brennan, Gleeson, and French Courts. While others have studied the Court in this period from a political science perspective, they have done so with a different focus to Galligan.

In 1999, David Solomon published The Political High Court, ${ }^{3}$ an engaging popular account of the High Court's decisions and their political consequences. Similarly, in 2000, in a book entitled Judging Democracy, ${ }^{4}$ Haig Patapan published a detailed study of the constitutional decisions of the Mason and Brennan Courts and the 'new politics' of constitutional interpretation on those courts. Patapan's focus was again on the political consequences of - rather than influences or determinants on - High Court decision-making. He sought to identify a coherent theory of politics, or democracy, immanent in the Court's decisions. In 2006, Jason Pierce published a study of the Mason Court - Inside the Mason Court Revolution: The High Court of Australia Transformed ${ }^{5}$ - more squarely in line with Galligan's original study. Pierce charted a marked shift, between the mid-1980s and 1990s in Australia, from an orthodox 'legal' or 'legalist' approach to the judicial role toward one that is more overtly 'political' or policy-oriented in nature. He explored a range of contextual factors that might explain this shift, including the external political context, suggesting that 'state and national governments encouraged, or were at least complicit with, components of the transformation'. 6 Pierce's study gave only brief consideration to the subsequent Brennan and Gleeson Court eras ${ }^{7}$ and none at all to the French Court. In 2015, it seems more than overdue for us to renew and extend Galligan's original focus on broad trends in the relationship between politics and constitutional law in Australia.

This gap in Australian scholarship seems even more striking when one considers the increasing richness of the literature in the United States on the relationship between constitutional law and politics. In 1957, American political scientist Robert Dahl published an article entitled 'Decision-Making in a Democracy: The Supreme Court as a National Decision-Maker, ${ }^{8}$ which showed a striking parallel between the decisions of the United States Supreme Court and the substantive policy positions or preferences of 'law-making majorities' in the

2 Brian Galligan, Politics of the High Court: A Study of the Judicial Branch of Government in Australia (University of Queensland Press, 1987) 22.

3 The Political High Court: How the High Court Shapes Politics (Allen \& Unwin, 1999).

4 Judging Democracy: The New Politics of the High Court of Australia (Cambridge University Press, 2000).

5 (Carolina Academic Press, 2006).

6 Ibid 236.

7 Ibid 257-88.

8 (1957) 6 Journal of Public Law 279. 
United States Congress. The 'policy making viewed on the Court', he suggested in a Galligan-style realist vein, are 'never for long out of line with the policy views dominant among the law-making majorities of the United States'. ${ }^{9}$ He concluded the United States Supreme Court 'is inevitably a part of the dominant national alliance'. ${ }^{10}$

In 1960, in a more historical vein, Robert McCloskey published a pathbreaking work entitled The American Supreme Court, ${ }^{11}$ which mapped the relationship between the United States Supreme Court's constitutional jurisprudence and broader political and historical developments in the United States. The lesson to be drawn from this history, McCloskey argued, was consistent with Dahl's findings: the Supreme Court according to McCloskey is a 'political institution' and behaves accordingly: it consistently adjusts its decisions to fit political developments and constraints. ${ }^{12}$ The Court, McCloskey suggested, 'seldom strayed far from the mainstreams of American life'. He suggested it was hard to identify a single instance 'when the [Supreme] Court has stood firm for very long against a really clear wave of public demand'. ${ }^{13}$

More recently, this work by Dahl and McCloskey has been updated and enriched by the detailed historical analyses of Lucas Powe and Barry Friedman. In The Supreme Court and the American Elite, $1789-2008,{ }^{14}$ Powe demonstrates the connection between the opinions and priorities of political elites in America and key Supreme Court decisions. In The Will of the People: How Public Opinion Has Influenced the Meaning of the Constitution, Friedman provides a richly detailed account of the parallels between elite and broader public opinion and the decisions of the United States Supreme Court - all the way to the Roberts Court. ${ }^{15}$

This book attempts to fill this gap in the Australian literature -in both temporal and comparative terms - by bringing together leading Australian constitutional lawyers and political scientists to reflect on the relationship between the constitutional jurisprudence of the High Court of Australia and broader currents in electoral politics and public opinion in Australia.

Defining the boundaries of the small 'c' constitution is notoriously difficult. One approach is to define such norms in terms of their degree of de facto political entrenchment; another in terms of their centrality in defining the sources of, and limits on, government power; and another still on the connection between such norms and fundamental aspects of national identity. ${ }^{16}$ In Australia, it is

9 Ibid 285.

10 Ibid 293.

11 (University of Chicago Press, 1960).

12 Ibid 261. See also G Rosenberg Comment at ibid 682.

13 Ibid 260.

14 (Harvard University Press, 2009).

15 See, eg, Barry Friedman, The Will of the People: How Public Opinion Has Influenced the Supreme Court and Shaped the Meaning of the Constitution (Farrar, Straus and Giroux, 2009) 369: 'the long-run fate of the Roberts Court is not seriously in doubt; its decisions will fall tolerably within the mainstream of public opinion, or the Court will be yanked back into line'.

16 Rosalind Dixon and Eric Posner, 'Limits of Constitutional Convergence' (2011) 11 University of Chicago Journal of International Law 399. 
impossible to develop a meaningful understanding of the capital ' $\mathrm{C}$ ' Constitution without some form of attention to small 'c' constitutional norms. Core parts of the Australian constitutional system, such as the institution of responsible government, are not mentioned in the text of the Commonwealth Constitution. Common law traditions and norms governing the rule of law, and protecting individual liberty, are arguably equally important and lacking express recognition in the Constitution's text.

Contributors to this book consistently raise important and serious methodological questions for any study of the constitutional law-politics relationship: for example, what does it mean to talk about 'national' majority opinion in a federal system? Can we, against such a backdrop, talk meaningfully about national political currents or opinion without denying our status as a federal system? And if so, what role is there for state governments or state-level breakdowns in opinion in answering this question? Michael Coper, for example, in Chapter 3 discusses the 2013 decision of the High Court to invalidate the Australian Capital Territory's same-sex marriage law (on the grounds of inconsistency with federal law) and notes that, while it may not have 'contradicted national sentiment', it 'contradicted the majority view of the local legislature'. ${ }^{17}$ He similarly notes the tension between national and state opinion on issues such as live-betting. In discussing the Dixon Court, Helen Irving notes that: 'In invalidating few Commonwealth laws, the Dixon Court may be counted as "majoritarian", but the relatively high rate of invalidation of state laws must also be taken into account. State governments have their own majorities and mandates'. ${ }^{18}$ In their chapter on the Gibbs Court, Nicholas Aroney and Haig Patapan note that:

In a federation such as Australia, there are at least two orders of government: the Commonwealth and the States. What if there are different governments at each level, and what if these governments reflect differences in public opinion across jurisdictions? Is the High Court being countermajoritarian or promajoritarian when it strikes down (or upholds) federal (or state) legislation on federalism grounds? ${ }^{19}$

Similarly, what do we think about the Commonwealth Parliament as a proxy for national majority opinion given that governments enjoy varying degrees of support in the House of Representatives and the Australian Parliament is bicameral ${ }^{20}$ John Williams, for example, discussing the Griffith Court, refers to the instability of political arrangements within the Commonwealth Parliament in its early years: 'The early parliaments were marked by division within the nonLabor forces and factions within Labor. Given these circumstances, it is difficult to isolate a majoritarian mood that is either counter to or in harmony with the High Court's pronouncements' ${ }^{21}$ During the period of the Griffith Court there

17 See Coper in Chapter 3 at p. 56.

18 See Irving in Chapter 10 at p. 199.

19 See Aroney and Patapan in Chapter 12 at p. 241.

20 Ibid.

21 See Williams in Chapter 5 at p. 84 
were 10 governments. 'The relationship over this period between the Court, the various governments, and parliament is complex given the shifting majorities and inherent instabilities of Australian politics' ${ }^{22}$ Similarly, Tony Blackshield notes that 'Isaacs became Chief Justice at a turbulent time in Australian political life', in which the Scullin Government faced both an extremely hostile Senate and became progressively internally divided. ${ }^{23}$ In discussing the Duffy Court, Gabrielle Appleby also notes that politics at the time 'was divided and unpredictable'. ${ }^{24}$

Another question is what it means to talk about the federal 'government' as a proxy for public opinion in a system of responsible government, where constitutional norms require a separation between the executive and legislative majority? Fiona Wheeler, for example, argues that while the Chifley Government suffered a long line of defeats at the hands of the Latham Court, it is still not easy to classify the Court as counter-majoritarian or to argue that the Latham Court 'in striking down elements of Labor's "new order" - was inevitably out of step with national sentiment, at least in all cases'. Instead, Wheeler suggests that an argument can be made that the key cases of the Latham Court, 'far from disrupting the will of a majority, actually reflected the mood of the times' ${ }^{25}$ Likewise, in writing about the Mason Court, George Williams and Paul Kildea note that while there was strong criticism of the Court centring on the notion that 'the Court exceeded its legitimate bounds by appropriating to itself a power to remake the law, particularly the Constitution', ${ }^{26}$ it was far from clear that in handing down decisions such as $M a b o,{ }^{27}$ or recognising an implied right to political freedom, the Court was acting contrary to popular opinion: polls at the time indicated that the public was divided on Mabo, with neither solid majority support for it, nor broad public opposition against it. Surveys conducted regarding rights protection also indicated that Australians felt that rights were not sufficiently protected and believed the courts should have the 'final say' in deciding upon issues of basic rights and freedom, suggesting a public in favour of enhanced legal protections of rights and comfortable with the idea that the courts might be the institution that makes binding decisions about them. ${ }^{28}$

Finally, various contributors discuss what it means to talk about 'popular opinion' when public opinion is often unstable, voters have limited access to information or knowledge on constitutional questions, and there are so few reliable public opinion polls or surveys. Appleby, for example, notes that during the Duffy Court era, '[p]ublic opinion as measured at the ballot box varied widely'; there existed 'deep political and public divisions over questions of economic regulation and its social impact, amplified by the pressures of the Great

22 See John Williams in Chapter 5 at p. 95.

23 See Blackshield in Chapter 7 at p. 118.

24 See Appleby in Chapter 8 at p. 142.

25 See Wheeler in Chapter 9 at pp. 171-2.

26 See George Williams and Kildea in Chapter 13 at p. 244.

27 Mabo v Queensland (No 2) (1992) 175 CLR 1 ('Mabo').

28 See George Williams and Kildea in Chapter 13. 
Depression'. ${ }^{29}$ Williams and Kildea note the absence of any specific opinion polls on issues such as freedom of expression in Australia, let alone the Court's role in interpreting the Constitution so as to protect such a right, and on key issues that defined the Mason Court era. ${ }^{30}$ On other issues, such as the Court's Mabo decision recognising common law rights to native title, the results of various public opinion polls were extremely inconsistent. ${ }^{31}$ Similarly, in Chapter 16 on the French Court, Anika Gauja and Katharine Gelber note the divergent public responses to decisions such as M70 ('Malaysia Declaration Case'): ${ }^{32}$ many media commentators criticised the decision but two public opinion polls showed opposition to the government policy set aside by the Court. Those poll results, the authors suggest, may have been affected by 'question wording and survey methodologies'. ${ }^{33}$

In raising these questions and challenges, the contributors provide a rich range of different answers and perspectives on the law-politics relationship in Australian constitutional history. Three of the chapters in this book address these questions for the full span of High Court history. Chapter 2, by Russell Smyth and Vinod Mishra, addresses this question from a quantitative perspective. The authors measure the rate at which the High Court has invalidated legislation, comparing that with a variety of political factors. For lawyers, there will be obvious downsides to this kind of method of 'counting heads' - but the method is a core part of the American literature on this topic. The basic findings of Smyth and Mishra are striking from the perspective of subsequent, more qualitative contributions: they find marked differences between different eras on the Court in the rate at which federal legislation is invalidated and the rate at which legislation passed by the political party in power at the relevant time is invalidated.

Chapter 3, by Michael Coper, focuses on the relationship between the formal processes of amendment in s 128 of the Constitution and the direction of the Court's jurisprudence. Coper notes two important cases in which s 128 has been successfully used to override decisions of the High Court and bring about a greater alignment over time between public opinion and the High Court's constitutional jurisprudence: the 1977 amendment to create a mandatory minimum retirement age, which overrode the Court's 1918 decision requiring lifetime judicial tenure; and the 1946 amendment designed to overrule the Court's invalidation of a national pharmaceutical benefits scheme in the First Pharmaceutical Benefits Case, ${ }^{34}$ by giving the Commonwealth power with respect to a wide range of social services. In later chapters, other contributors set out in more detail the history of these various failed amendments, as well as the use (or non-use) by the Commonwealth Parliament at various times of more ordinary means of

29 See Appleby in Chapter 8 at pp. 142-3.

30 See George Williams and Kildea in Chapter 13 at p. 256.

31 Ibid 255-6.

32 Plaintiff M70/2011 v Minister for Immigration and Citizenship (2011) 244 CLR 144.

33 See Gauja and Gelber in Chapter 16 at p. 319.

34 Attorney-General (Vic); Ex rel Dale v Commonwealth (1945) 71 CLR 237 ('First Pharmaceutical Benefits Case'). 
legislative override, particularly in the context of various common law or small 'c' constitutional decisions. In the context of amendment, Coper notes instances in which such attempts at legislative override of Court decisions have failed, including the well-known 1951 attempt by the Menzies government to pass an amendment to override the Court's decision in the Communist Party Case ${ }^{35}$ to allow for the banning of the Australian Communist Party. ${ }^{36}$ A more complicated set of cases discussed by Coper are those in which amendments have failed to pass at a national referendum, but where the High Court has nonetheless developed constitutional law in a similar direction: in some cases, this could be said to have reflected national majority sentiment (as evidenced in the relevant referenda), but in others to ignore national majority opposition to equivalent change by the formal process of amendment.

Chapter 4, by Andrew Lynch, focuses on key dissenting judges and judgments in Australian constitutional history, with a view to considering the link between dissent and internal versus external political dynamics. The internal political dynamics within the Court are a central force behind dissenting judgments, Lynch suggests, but there is clearly some connection to external politics in terms of the degree to which the 'great dissenters' were appointed by governments seeking to give voice to a perspective other than that dominant on the Court during the relevant period.

The remainder of the chapters are divided into 12 distinct periods, which correspond to eras of different Chief Justices on the High Court. There are, of course, obvious difficulties with this kind of periodisation, as Sir Anthony Mason notes in the Foreword: for one, it takes the Court, rather than the government or political institutions, as the relevant focus of periodisation or analysis. For another, it ignores important sources of continuity between different eras on the Court, many of which are driven by the tenures of influential members of the Court other than the Chief Justice. Some form of periodisation is necessary, however, if one is to undertake this kind of multi-authored project. For some eras, various authors find, the Chief Justice has also been a reliable bell-weather for the current of High Court decision-making. In other eras, the Chief Justice may have only spoken for himself and not for a majority of the Court. Each of the chapters on specific Courts addresses this issue directly by identifying whether the relevant period is being studied in a 'weak' or 'strong' sense - as merely a nominal denomination of a particular time-period or as an era in which the Chief Justice was either influential on, or broadly in sync with, the decisions of other Justices. ${ }^{37}$

In exploring these different eras, some authors suggest there is little discernible relationship between the constitutional jurisprudence of the High Court

35 Australian Communist Party v Commonwealth (1951) 83 CLR 1 ('Community Party Case').

36 The decision is discussed in more detail in the chapters on the Latham and Dixon Courts (see Chapters 9 and 10).

37 Cf Theunis Roux, 'The Langa Court: Its Legitimofs and Legacy' [2015] Acta Juridica (forthcoming). See also the discussion in Mark Tushnet, The New Constitutional Order (Princeton University Press, 2003). 
and broader political currents. Instead, they suggest, the dynamics driving the Court's jurisprudence were often far more internal than external. Blackshield, for example, notes that while 'Isaacs became Chief Justice at a turbulent time in Australian political life', perhaps the most significant factor shaping the jurisprudence of the Isaacs Court was the appointment of Sir Owen Dixon. 'Almost from the moment of his appointment', Blackshield suggests, Dixon was the 'intellectual leader' of the Court. ${ }^{38}$ Together with Rich and Starke JJ, Dixon J was the author of key decisions, such as the ARU Case, ${ }^{39}$ which overturned key policies of the Scullin government (such as its extension of the powers of the Commonwealth Conciliation and Arbitration Commission). ${ }^{40}$ In the early years of the Barwick Court, Galligan likewise suggests that the Court was predominantly 'the Dixon Court in its approach and doctrines' ${ }^{41}$ Similarly, in writing about the Brennan Court, Patrick Emerton and Jeffrey Goldsworthy suggest that while the Court both 'consolidated' various changes wrought by the Mason Court and significantly expanded the Constitution's protection of judicial authority and independence in quite 'activist' ways, these trends 'seem more plausibly explained by the intellectual influence of particular judges, rather than by external political circumstances', including the appointment of two new Justices to the Bench by the Howard Government. ${ }^{42}$

In writing about the Gibbs Court, Aroney and Patapan doubt whether there is any immediate connection between the Court's decisions and surrounding political understandings. Instead, they suggest, the Court is best seen as a political institution, only in a more fundamental rather than immediate sense: as an institution that is shaped by internal political processes, 'an important part of the machinery of government in Australia', and delivers decisions with clear political and 'policy implications'. ${ }^{43}$ At most, they suggest, the Court is likely to be influenced by its immediate political context where that context directly threatens the Court's own institutional legitimacy. For the Gibbs Court, that meant 'consolidating - and defending - its political power and legitimacy' in the face of the controversy surrounding Murphy $\mathrm{J}$ and the public role played by Barwick CJ in the dismissal of Prime Minister Gough Whitlam. ${ }^{44}$

Others suggest a potentially closer relationship between constitutional law and broader political currents and understandings, but one that is highly complex and defies any ready classification of the High Court's jurisprudence as generally 'pro'- or 'counter'-majoritarian. In writing about the Knox Court, Anne Twomey suggests that: 'The Knox Court reshaped the federal system of government, conferring greater power on the Commonwealth' and in so doing 'supported the aims of federal governments of all political persuasions, but appeared to be

38 See Blackshield in Chapter 7 at p. 119.

39 Australian Railways Unionv Victorian Railways Commissioners (1930) 44 CLR 319 ('ARU Case').

40 Commonwealth Conciliation and Arbitration Act 1904 (Cth)

41 See Galligan in Chapter 11 at p. 204.

42 See Emerton and Goldsworthy in Chapter 14 at pp. 261-3.

43 See Aroney and Patapan in Chapter 12 at p. 242.

44 See Aroney and Patapan in Chapter 12 at p. 243. 
acting contrary to the wishes of the people who rejected such changes when put to them in referenda'. ${ }^{45}$ Twomey also notes the degree to which this shift was the product of a distinct confluence between political nationalism and legal conservatism on the High Court. ${ }^{46}$ In her chapter on the Duffy Court, Appleby suggests that during this period '[d] eference to democratic institutions is evident in some areas but not others', and that 'on questions of federalism and the parliamentary/executive relationship, the Court adopted a deferential interpretation that allowed the relevant political actors to resolve difficult economic and social questions', whereas 'on questions of government encroachment on the rights of minorities and vulnerable individuals, the Court stepped into the fray'. ${ }^{47}$

In the context of the Latham Court, Wheeler suggests that while 'doctrinal factors played an important part' in the decisions of the Latham Court, they did not 'lead inexorably to the results in question'. ${ }^{48}$ Rather, for the wartime cases of the Latham Court, Wheeler suggests that the Court 'became part of the national project to defeat the enemy, explicitly interpreting the Constitution to support the government's carriage of the war'; ${ }^{49}$ and for various decisions invalidating Labor's post-war initiatives, 'conservative political resistance to socialism' seems to have been an important factor. ${ }^{50}$ At the same time, Wheeler notes that the Latham Court's constitutional decision-making was also characterised by stark contrasts: 'deference to parliament and the executive during World War II followed by a vigorous approach to judicial review in the post-war period that saw the demise of key parts of the Chifley Government's policy platform'. ${ }^{51}$ Irving, in her chapter on the Dixon Court, argues that: 'the Commonwealth government in power throughout the Dixon era was rarely displeased'. ${ }^{22}$ Indeed, she suggests 'the conservative values of the Court appear to have aligned with the majority conservative culture of the time'. ${ }^{53}$ At the same time, Irving notes the clear exception to this pattern provided by the Communist Party Case, ${ }^{54}$ a decision decided during the Latham Court period, but 'led by Dixon', which 'demolished the centrepiece of [Menzies'] cherished plan to rid Australia of communism'. 55

Galligan, in surveying the 'second phase' of the Barwick Court, suggests that the Court carried out its constitutional role "broadly in accord with the overall federal mood'. ${ }^{56}$ Despite the gap in the political views of Barwick CJ and some of his fellow Justices and the Labor Government under Whitlam, "[t]here was no repeat of the Chifley era of "Labor versus the Constitution", when the

45 See Twomey in Chapter 6 at p. 114.

46 See Twomey in Chapter 6 at p. 103.

47 See Appleby in Chapter 8 at p. 143.

48 See Wheeler in Chapter 9 at p. 172.

49 See Wheeler in Chapter 9 at p. 177.

50 See Wheeler in Chapter 9 at p. 176

51 See Wheeler in Chapter 9 at p. 159

52 See Irving in Chapter 10 at p. 180.

53 See Irving in Chapter 10 at p. 199.

54 Australian Communist Party v Commonwealth (1951) 83 CLR 1 ('Communist Party Case').

55 See Irving in Chapter 10 at p. 200.

56 See Galligan in Chapter 11 at p. 214. 
High Court gutted the nationalisation program of the Labor Government and vetoed its more centralist legislation'. ${ }^{57}$ At the same time, Galligan notes certain clear exceptions to this pattern in the areas of $s 92$ of the Constitution (and the Court's laissez faire reading of guarantee of freedom of interstate trade and commerce) and the interpretation of tax legislation. ${ }^{58}$

In the more modern era, Williams and Kildea suggest, in writing about the Mason Court, that: 'Even if its critics are right, and the Court did exceed is institutional bounds, it may be that it did so in a way that developed the law in conformity with community attitudes. It may even be that public opinion supported the Court moving beyond orthodox understandings of its role'. ${ }^{59}$ At the same time, the chapter notes the degree to which there is limited evidence on what community attitudes were on many of the issues facing the Mason Court, and that there is insufficient evidence to conclude that the Mason Bench acted either contrary or in line with popular majorities. In discussing the Gleeson Court, Rosalind Dixon and Sean Lau argue that the Gleeson Court was 'in a very immediate sense a court of the Howard era', with five of the Justices who served with Gleeson CJ (including Gleeson CJ himself) appointed by Howard; and "many key capital "C" Constitutional cases during the Gleeson Court era... upholding the politically conservative policies of the Howard Government'. ${ }^{60}$ At the same time, the chapter argues that these decisions seemed far more the "product of a commitment on the part of a majority of the Court to a distinct form of legal, rather than political conservatism' ${ }^{61}$ - a small ' $c$ ' conservative legal philosophy that favoured judicial modesty or restraint, rather than strict textualism or originalism and deference to the Commonwealth Parliament. Further, where this form of legal conservatism clashed with Howard-style political conservatism-as it did in the migration areait was this form of legal rather than political conservatism that tended to take precedence.

Similarly, in writing about the French Court to date, Gauja and Gelber note that: 'While some of the Court's decision-making can be analysed in a majoritarian versus countermajoritarian frame, other components cannot', and moreover that ' $[\mathrm{t}]$ hose cases that are suited to this frame diverge in the sense that the definition of the "majority" at play differs considerably, with public opinion, legislative majorities, elite commentary, and partisanship all playing a role'. ${ }^{62}$

In drawing these connections, various authors explore two broad mechanisms as potential sources of alignment or non-alignment between the Court and broader political currents, in addition to amendment or legislative override: first, the process of judicial appointment; and second, the Court's self-conscious consideration of the broader political context.

57 See Galligan in Chapter 11 at p. 206.

58 See Galligan in Chapter 11 at pp. 214-16.

59 See George Williams and Kildea in Chapter 13 at p. 245.

60 See Dixon and Lau in Chapter 15 at p. 284.

61 See Dixon and Lau in Chapter 15 at p. 285.

62 See Gauja and Gelber in Chapter 16 at p. 326. 
For the process of judicial appointment, the most extreme example of how this can influence the Court's approach in constitutional cases is where a government is willing to adopt legislation altering the size of the Court, in order to create a deliberate opportunity to appoint new judges. The most famous example of this tactic in the United States was the 'court packing' plan President Franklin Delano Roosevelt sent to Congress in 1937, in response to a series of Supreme Court decisions striking down core aspects of his (enormously popular) 'New Deal Program' or Depression-era economic reconstruction efforts. While the proposed legislation (the Judicial Procedures Reform Bill of 1937) never actually came to a floor vote in this form, the Court - and specifically Owen Roberts J - around the same time dramatically shifted position to uphold minimum wage laws as consistent with the right to freedom of contract protected by the Due Process Clause. Many leading American scholars, including Friedman, credit the threat of courtpacking as an important factor in this 'switch in time' - or political-constitutional re-alignment - by Roberts J. ${ }^{63}$ Similarly, in Australia the Chifley Government twice actively considered a proposal to increase the size of the High Court from six to nine, in order to allow it to appoint a majority of Justices sympathetic to its economic nationalisation agenda. It also attempted to pack the existing Court of six by attempting to recall Sir William Webb from his duties as President of the International Military Tribunal to sit on the Bank Nationalisation Case. ${ }^{64}$ As Wheeler notes on her chapter on the Latham Court, neither proposal ultimately came to fruition: the 1945 court-packing plan was successfully resisted by AttorneyGeneral Evatt, and the second attempt came to nothing. The attempt to recall Sir William Webb to Australia was similarly ineffective: Webb stayed on in Tokyo and Latham CJ met with Solicitor-General Kenneth Bailey and strongly protested the Government's interference in the Bench in a matter to which it was a party.

In some cases, ordinary processes of judicial appointment can also create opportunities for an alignment between federal government policy and constitutional jurisprudence. As Galligan notes in his contribution: while '[t]he High Court operates outside ordinary politics - of party, parliament, and executive' it is a 'major player in constitutional politics'; and the process of judicial appointments by the executive provides 'a crucial crossover between the two' ${ }^{65}$ The process of judicial retirement and appointment of a new Justice allows the elected government to affirm the direction of the Court's jurisprudence as within the bounds of majority or community opinion, by appointing a judge with a similar legal or political philosophy; or else to seek to redirect the course of the Court's decisions, by appointing a judge who is known to favour a distinctive approach to interpretation.

There has been a clear history of various governments in Australia relying on this kind of overtly political calculus in making appointments to the High Court,

63 See, eg, Friedman, The Will of the People, above n 15, $250-8$.

64 Bank of New South Wales v Commonwealth (1948) 76 CLR 1 ('Bank Nationalisation Case').

65 See Galligan in Chapter 11 at p. 202. 
particularly in the context of appointments of serving members of parliament. As Blackshield notes, Evatt and McTiernan JJ were both serving Labor politicians who were appointed to the Court in what was widely viewed as a political attempt to 'pack' the Court so as to ensure that it would uphold various ALP nationalisation and social welfare policies. ${ }^{66}$ Chief Justice Latham, as Wheeler explains, was a well-known conservative member of federal parliament before his appointment as Chief Justice. ${ }^{67}$ Chief Justice Barwick, as Brian Galligan notes, was not only a senior minister in the Liberal appointing government, but 'clearly a political appointment'. ${ }^{68}$ And Murphy J was Attorney-General in the Whitlam Government. ${ }^{69}$

There are three factors in Australia that increase the potential for judicial appointment processes to create such alignment. First, since 1977 Australia has had a mandatory retirement age of 70 for federal judges. While it is far less common than in the United States for members of the Court to time their retirement to allow a particular government to appoint their successor (the only clear example of this practice in Australia, as Wheeler notes, was the decision of Rich and Starke JJ not to retire until 1950, after the Liberal Government returned to power), there is often significant turnover in the composition of the Court during a particular government. Second, unlike many other common law countries, Australia has thus far resisted attempts to introduce any form of public or parliamentary 'vetting' or confirmation for potential judicial appointees. ${ }^{70}$ This gives the federal government broad power to appoint its own preferred candidates for judicial office to the Court. Third, as Dixon and Lau note in discussing the Gleeson Court, the relatively small nature of the legal and political community in Australia means that - serving members of parliament aside governments often have strong knowledge of the views of potential nominees on a range of issues. In the context of the Griffith Court, for example, Williams discusses the 'close relationship that existed between the framers, the political leaders, and the Court'. ${ }^{71}$ In the context of the Dixon Court, Irving refers to the friendship between Prime Minister Robert Menzies and Dixon CJ and the fact that both Kitto and Taylor JJ had been members of the successful legal team for the banks against the Chifley Labor Government's bank nationalisation legislation in 1948, 'a feat that no doubt commended them to Prime Minister Menzies' ${ }^{72}$ Galligan explores the relationships between members of the Whitlam and Howard/Keating Governments and Jacobs, Brennan, and Wilson $\mathrm{JJ},{ }^{73}$ and Dixon notes (with Lau) the multiple areas of professional overlap between Chief Justice Murray Gleeson and Prime Minister John Howard. ${ }^{74}$

66 See Blackshield in Chapter 7 at pp. 117-18.

67 See Wheeler in Chapter 9 at p. 160.

68 See Galligan in Chapter 11 at p. 203.

69 See Galligan in Chapter 11 at p. 209.

70 See, eg, George Williams, 'High Court Appointments: The Need For Reform' (2008) 30 Sydney Law Review 163-69.

71 See Williams in Chapter 5 at p. 78.

72 See Irving in Chapter 10 at p. 182.

73 See Galligan in Chapter 11 at pp. 207-8.

74 See, eg, Dixon and Lau in Chapter 15. 
At the same time, from the outset in Australia the practice of governments considering the political views of potential judicial appointees has been controversial. Williams, for example, cites the early controversy over the attempt by the Labor Attorney-General, William Morris Hughes, to identify a judge with known centralist sympathies in making appointments to fill the two new seats created on the Court in 1913. Piddington J was forced to bow to public pressure and resign from the Court, only one month after being appointed, after it emerged that 'Hughes had attempted to ascertain Piddington's views on Commonwealth power as a condition of the appointment'. ${ }^{75}$ Similarly, Blackshield explains that both Evatt and McTiernan JJ were appointed against the objections of the then Labor Prime Minister James Scullin: Scullin, as Blackshield notes, had previously been critical of political appointments to the Bench and was anxious to avoid the appointment of overtly political figures to the Court. It was only while Scullin was sailing back from Europe with the Attorney-General that the acting Attorney-General successfully appointed Evatt and McTiernan to the Court.

The practice has become even more controversial in recent decades, following the appointment of Murphy J. Not only was Murphy's appointment itself highly controversial - as Galligan says, it caused a political 'furore ${ }^{76}$ - but on the Bench, Murphy $\mathrm{J}$ was 'a radical and a deliberate innovator who viewed the Court and judges as agents of social change'. ${ }^{77}$ Aroney and Patapan discuss the controversy surrounding Murphy J's alleged attempt to pervert the course of justice by attempting to pressure a magistrate in relation to committal hearings involving a friend of Murphy (the solicitor Morgan Ryan). ${ }^{78}$ While a Parliamentary Commission of Inquiry over the allegations was terminated after it was announced that Murphy had terminal cancer, the controversy surrounding the allegations continued, despite Murphy's acquittal on all criminal charges. Since that time, no government in Australia has appointed a judge to the High Court with overtly political sympathies or connections to electoral politics.

This shift has also been amplified by an increasing consensus or convergence of interests among both major political parties in Australia over the legal and political philosophy that is desirable on the Court. There have been times in Australia's constitutional history where a battle over constitutional rights - such as the right to 'just terms' upon any acquisition of property by the Commonwealth have been the subject of major partisan significance. A prominent example is the High Court's decision in the Bank Nationalisation Case, ${ }^{79}$ in which (in one of several strands of reasoning) certain members of the Court applied the 'just terms' guarantee and the protection of interstate trade and commerce to strike down the Chifley Government's attempt to nationalise Australia's private banks. This gave rise to a sense that the High Court's interpretation of the Constitution had been

75 See John Williams in Chapter 5 at p. 83, n 34.

76 See Galligan in Chapter 11 at p. 210.

77 See Galligan in Chapter 11 at p. 210.

78 See Aroney and Patapan in Chapter 12.

79 (1948) 76 CLR 1. 
constructed to defeat Labor's political objectives. This idea was most famously encapsulated in the 1957 Chifley Memorial Lecture, delivered by future Prime Minister Gough Whitlam, which he entitled 'The Constitution versus Labor'.

Despite such concerns, constitutional rights guarantees have not proven a major obstacle to either federal ALP or Coalition government policy in Australia. The key constitutional obstacle for both sides of politics has been the potential for a narrow reading of the express sources of legislative power granted to the Commonwealth under s 51 of the Australian Constitution or a strict reading of structural requirements such as the separation of powers. This explains significant defeats suffered by federal governments in the High Court, including the decision in the Communist Party Case to strike down Menzies Government legislation banning that political party ${ }^{80}$ and that in the Incorporation Case striking down the Hawke Government's attempt to unilaterally bring about a national corporations law. ${ }^{81}$ On these issues, in the modern High Court era there has been increasing consensus - rather than disagreement - among the two major political parties in Australia that it is desirable to appoint judges with a broad view of Commonwealth power. This has, at times, led to more or less a bipartisan commitment to appointing lawyers who are identifiable 'legal' - if not political conservatives. Appointments in Australia have often tended not to be partisan in the sense that they are seen as having any affiliation with one or other side of politics. Instead, both sides of politics have sought to appoint judges who might assert an interpretation of the Constitution supportive of Commonwealth power even where this has meant giving less weight to the political, as opposed to legal, views of potential nominees.

In analysing the constitutional law-politics relationship, a second factor authors consider is the degree to which the High Court may have consciously considered the broader political context for its decisions - as either a prudential factor relevant to the Court's perceived institutional legitimacy and standing or as informing the content of certain normatively-laden doctrinal tests. At times, various authors suggest the Court may have been willing to defer to national government policies out of a particular concern for the institutional standing or perceived legitimacy of the Court itself. Appleby, for example, in her chapter on the Duffy Court suggests that, while decisions such as the Garnishee Cases ${ }^{82}$ could clearly be explained by orthodox legalism and the avowed adherence of Dixon, Rich, and Starke JJ to such methods, 'another factor that would have been present in the mind of Dixon J, if not the other judges, was the importance of maintaining confidence in the judiciary' and avoiding the Court becoming a 'playe[r] in a public state-federal dispute over economic and social questions that split the Australian community'. ${ }^{83}$

80 (1951) 83 CLR 1.

81 New South Wales $v$ Commonwealth (1990) 169 CLR 482 ('Incorporation Case').

82 New South Wales v Commonwealth (No 1) (1932) 46 CLR 155 ('First Garnishee Case'); New South Wales $v$ Commonwealth (No 2) (1932) 46 CLR 235 ('Second Garnishee Case'); New South Wales $v$ Commonwealth (No 3) (1932) 46 CLR 246 ('Third Garnishee Case').

83 See Appleby in Chapter 8 at p. 149. 
Conversely, in other contexts, Appleby suggests that the absence of such prudential concerns may have encouraged the Court to take a more active role in protecting minority rights. The Court was able to assume such a role, Appleby suggests, 'without too great a risk to its legitimacy' because '[a]t a time when the political branches were rife with divide and otherwise occupied by the economic crisis', members of the Court could pursue this agenda 'without fear of subsequent government intervention and damage to their, and the Court's, reputation' ${ }^{84}$ Wheeler likewise notes, in the context of the Latham Court, that while the decision to defer to various wartime measures was clearly explicable on orthodox legal grounds, it also furthered the Court's 'wider quest', to project itself as above political affairs and thereby as a legitimate legal institution. ${ }^{85}$ Similarly, in other contexts, authors note the degree to which a concern for the Court's perceived standing may have influenced the Court to take a more active role in striking down legislation or assuming a role in protecting individual common law liberties. Twomey, for example, in discussing the Knox Court notes that in Re Judiciary and Navigation Acts $^{86}$ the Court struck down the validity of legislation giving it an advisory jurisdiction, arguably in order to avoid becoming embroiled in political matters.

Some authors suggest that the Court may even have consciously considered various dominant political understandings or attitudes in giving content to various constitutional tests or concepts. Irving, for example, in writing about the Dixon Court's various common law decisions, notes the degree to which Dixon $\mathrm{CJ}$ and other judges gave effect to a certain kind of personally or politically conservative set of values regarding marriage and divorce. This, she suggests, was an almost inevitable product of the Court's role in supervising the exercise of judicial discretion under state law. As Irving notes, "[t]he exercise of discretion evades a strict application of legal principles; it necessarily calls for a judgment about extra-legal values' ${ }^{87}$ Similarly, in writing about the Gleeson Court, Dixon and Lau suggest that there were cases decided by the Court in which a certain kind of political conservatism exerted an influence on the direction of the Court's jurisprudence but these were areas in which existing case law (and legalist or legally conservative methods) necessarily called for the making of an inherently normative or political judgment. Examples in this category include the application of notions of 'reasonable' care and a public policy exception in tort law; the doctrine of 'legitimate' expectations in administrative law; and 'reasonable proportionality' under the implied freedom of political communication. ${ }^{88}$

What, one might still ask, is the value of studying the relationship between constitutional law and broader political developments? Coper, for example, directly raises this challenge, suggesting that 'direct appeal to the people [and their views] should not blind us to an appropriately sophisticated understanding of the place

84 See Appleby in Chapter 8 at pp. 154, 157.

85 See Wheeler in Chapter 9 at p. 163.

86 (1921) 29 CLR 257.

87 See Irving in Chapter 10 at p. 197.

88 See Dixon and Lau in Chapter 15. 
of judicial review in a democracy'. ${ }^{89}$ Judicial review, Coper suggests, helps promote and protect the rule of law and a system of checks and balances that is essential to a 'sophisticated notion of democracy'. ${ }^{90}$ Similarly, in discussing a decision on access to the franchise, Gauja and Gelber note that, while invalidating a (then majority) government policy, the decision could be seen as 'strongly majoritarian in seeking to ensure the broadest enfranchisement of the people, in order that they may select their own government'. ${ }^{91}$ It is potentially quite misleading to focus on the relationship between judicial review and more populist notions of democratic will or majority understandings.

We believe there are, however, at least three reasons to value a study of the relationship between constitutional law and politics. First, law is not produced in a vacuum. It is a product of its times and of the broader social and political context. To understand that context is to better understand the law itself and particularly the likely direction of its evolution: 'The life of the law', as Oliver Wendell Holmes famously put it, 'has not been logic; it has been experience'. ${ }^{92}$

Second, to understand the High Court's effectiveness as an institution, it is important to understand its relationship to the political process: if the Court's decisions are frequently out-of-step with broader political understandings, yet consistently respected and enforced, we can expect future decisions to have similar effect. In contrast, if the Court's decisions are in line with prevailing political currents, we can be less confident in making such a prediction about any future decision that is distinctly more countermajoritarian.

Third, we believe, there are, at the very least, important normative questions to be asked about the relationship between constitutional law and broader democratic understandings in certain contexts. Constitutional law, like other forms of law, is a form of law which requires judges to employ an orthodox set of legal techniques and methods in deciding specific controversies. ${ }^{93}$ But it is also an area of law that is particularly likely to involve more open-ended evaluative judgments or judgments of an inherently political character - political not in the 'capital P' sense of partisan political, but in the broader sense of involving issues with direct implications for social or political justice. Constitutions are often phrased in quite broad or abstract, or 'framework-like', language. ${ }^{94}$ Language of this kind is sufficiently open-ended such that many questions of constitutional interpretation cannot be answered by reference to orthodox legal techniques or formal legal materials alone. Instead, they require judgment on the part of the Court about political questions - such as the degree of deference that should be afforded to parliament on certain questions, the most appropriate level of government to carry out certain legislative or policy functions, or the balance between majority

89 See Coper in Chapter 3 at p. 54.

90 See Coper in Chapter 3 at p. 55.

91 See Gauja and Gelber in Chapter 16 at p. 316.

92 Oliver Wendell Holmes, The Common Law (Macmillan, 1881) 1.

93 Compare Marbury v Madison 5 US 137 (1803).

94 Rosalind Dixon, 'Partial Constitutional Amendments' (2011) 13 Journal of Constitutional Law 643. 
opinion and minority rights claims. In answering these questions, theorists such as Jeremy Waldron have suggested that there is an important argument that courts should in fact be mindful of broadly shared community values or political understandings..$^{95}$

The question of the relationship between the High Court and politics is not one that we, or any of the other authors, purport to answer. But to even begin to answer it, it seems important to know what the facts are: are we starting from a position where the Court seems largely to ignore - or to be out-of-step with-popular attitudes and is there what Americans have called a 'counter-majoritarian difficulty' with judicial review? ${ }^{96}$ Or are we starting from the position that the Court is largely in-step with popular understandings or expectations regarding the distribution of political power? If so, the key question for Australian constitutional lawyers and political scientists might not be whether the Court should do more to respect democracy but whether it can do more to enrich or enhance its depth.

95 See, eg, Jeremy Waldron, Law and Disagreement (Oxford University Press, 1999). See also Adrienne Stone, 'Judicial Review Without Rights' (2008) 28 Oxford Journal of Legal Studies 1.

96 Alexander Bickel, The Least Dangerous Branch: The Supreme Court at the Bar of Politics (Yale University Press, 1986); Barry Friedman, 'The History of the Countermajoritarian Difficulty, Part One: The Road to Judicial Supremacy' (1998) 73 New York University Law Review 333. 